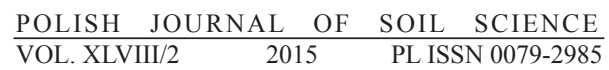

DOI: $10.17951 / \mathrm{pjss} / 2015.48 .2 .241$

Soil Genesis

\author{
JERZY JONCZAK*, VLADIMÍR ŠIMANSKÝ**, \\ NORA POLLÁKOVÁ**
}

\title{
CHARACTERISTICS OF IRON AND ALUMINIUM FORMS AND QUANTIFICATION OF SOIL FORMING PROCESSES IN CHERNOZEMS IN WESTERN SLOVAKIA
}

\begin{abstract}
The studies on iron and aluminium forms and soil forming processes quantification in Chernozems were conducted in two localities in Western Slovakia. Two soil pits were done in a complex of arable Haplic Chernozems in Krakovany and two soil pits representing arable and forest Cambic Chernozems were done in Báb. The soils were sampled every $10 \mathrm{~cm}$ and analysed using standard methods. Based on analytical results, profile development indices (PDI) were calculated for each profile. Chernozems in Krakovany were characterised by $90 \mathrm{~cm}$ (Krakovany 1) and $80 \mathrm{~cm}$ (Krakovany 2) thick solums and $\mathrm{pH}$ increasing with depth from neutral to alkaline. The content of total organic carbon (TOC) was up to $13.70 \mathrm{~g} \mathrm{~kg}^{-1}$ in both profiles. Cambic Chernozems in Báb were characterised by a lower thickness of solum $-40 \mathrm{~cm}$ in arable soil (Báb 1) and 70 $\mathrm{cm}$ in forest soil (Báb 2). Reaction of arable soil ranged from slightly acid to alkaline, and in the case of forest soil - from strongly acid to alkaline. Arable soil contained 14.2-14.5 g kg-1 , and forest soils 12.9-50.7 $\mathrm{g} \mathrm{kg}^{-1}$ of TOC in A horizons. The content of $\mathrm{Fe}_{\mathrm{t}}$ in the studied soils ranged from 21.78 to $32.48 \mathrm{~g} \mathrm{~kg}^{-1}$, free iron oxides $\left(\mathrm{Fe}_{\mathrm{d}}\right)$ - from 5.74 to $11.53 \mathrm{~g} \mathrm{~kg}^{-1}$, and amorphous iron oxides $\left(\mathrm{Fe}_{\mathrm{o}}\right)$ - from 0.77 to $2.94 \mathrm{~g} \mathrm{~kg}^{-1}$. $\mathrm{Fe}_{\mathrm{d}} / \mathrm{Fe}_{\mathrm{t}}$ ratios ranged from 0.26 to 0.39 . Crystalline forms predominated over amorphous ones. The values of PDI were relatively low, namely $1.50-$ in the profile Krakovany 1; 1.76 - in the profile Krakovany 2; 1.15 in the profile Báb 1 and 2.12 - in the profile Báb 2.
\end{abstract}

*J. Jonczak, DSc.; Department of Geoecology and Geoinformation, Pomeranian University in Słupsk, Partyzantów 27, 76-200 Słupsk, Poland.

** Prof. V. Simansky, DSc.; N. Pollakova, DSc.; Department of Soil Science, Slovak University of Agriculture in Nitra, Tr. A. Hlinku 2, 94976 Nitra, Slovakia. 
Total content of $\mathrm{Fe}$ and $\mathrm{Al}$ in soils is conditioned mainly by primary abundance of parent materials. Progressively released as a result of weathering, metals form complexes with the remaining components of soils, particularly with clay minerals and organic matter, and are included into biological turnover. However, the amount which is included into the biological turnover is very small as compared to solis that are even poor in these elements. The content of $\mathrm{Fe}$ and $\mathrm{Al}$ in litterfall is usually kept within tenths or even hundredths of $\mathrm{g} \mathrm{kg}^{-1}$ of its dry weight and their annual influx to the soil together with litter in temperate forests rarely exceeds one kilogram per hectare $[13,14]$. Low contents of $\mathrm{Fe}$ and $\mathrm{Al}$ are also noticed in Oi sub-horizon of forest soils. Increasing contents in $\mathrm{Oe}$ and $\mathrm{Oa}$ sub-horizons are due to increasing admixture of mineral particles. Contamination of decaying materials by fine soil mineral fractions is also the main reason for commonly observed increasing trends in $\mathrm{Fe}$ and $\mathrm{Al}$ content during experiments on litterfall decomposition, using the litter-bag method $[8,15]$.

Free iron oxides strongly influence some properties of soils, especially their specific surface area and sorptive capacity [5] and play an important role in stabilising labile organic matter $[9,17]$ as well as immobilisation and migration of other metals [3]. The content and profile distribution patterns of free iron oxides, degree of their crystallisation and complexation with organic matter are crucial criteria in the assessment of the degree of soil mineral substrates transformation during pedogenesis and advancement of some soil-forming processes $[1,6,7,10$, $18,19,20]$.

The aim of our study has been to characterise iron and aluminium forms and to determinate the quantitative indices of soil profiles development in arable and forest Chernozems of Western Slovakia in two locations - Krakovany and Báb.

\section{MATERIAL AND METHODS}

\section{Stands characteristics}

The study comprised two profiles of arable Haplic Chernozems located near Krakovany $\left(48^{\circ} 36^{\prime} 39.62^{\prime \prime} \mathrm{N} 17^{\circ} 45^{\prime} 7.28^{\prime \prime} \mathrm{E}\right)$ and two profiles of arable and forest Cambic Chernozems near Báb (48 18’37.23”N 1752'5.72”E). Average annual temperatures for Krakovany are $8.5-9.0^{\circ} \mathrm{C}$ and annual sums of precipitation are between 650 and $800 \mathrm{~mm}$ whereas for Báb $-10.2^{\circ} \mathrm{C}$ and $436-680 \mathrm{~mm}$, respectively [24]. The Chernozems developed from Pleistocene loess were for many centuries cultivated and only small patches of those soils function under forest vegetation. Soya (Glycine max L.) in the stand Krakovany 1 and sunflower (Helianthus annus L.) in the stands Krakovany 2 and Báb 1 were grown during the study year. The tree stand in the locality Báb 2 was composed of unevenly aged but generally older than 100-year-old red oak (Quercus rubra L.) 
and Austrian oak (Quercus cerris L.) with admixture of sycamore maple (Acer pseudoplatanus L.) and hawthorn (Crataegus L.).

\section{Soil sampling and analysis}

One soil pit was done in each stand and classified in conformity with the WRB 2014 soil classification system [12]. Soil colour was determined in fresh samples in conformity with the Munsell Soil Color Charts [23]. Each soil was sampled every $10 \mathrm{~cm}$. One sample with disturbed structure and three $250 \mathrm{~cm}^{3}$ samples of undisturbed structure were collected from every layer. The following analyses were performed:

- particle density $\left(\rho_{s}\right)$ by means of pycnometry,

- bulk density $\left(\rho_{\mathrm{d}}\right)$ and actual moisture $(\theta)$ by means of the gravimetric method,

- total porosity based on the bulk and particle densities, calculated according to the formula $\left(\left(\rho_{\mathrm{s}}-\rho_{\mathrm{d}}\right) / \rho_{\mathrm{s}}\right) \cdot 100$,

- $\mathrm{pH}$ in soil-water suspension by means of the potentiometric method (1:2.5 - soil:water),

- the content of carbonates by means of the Scheibler method,

- the content of total organic carbon (TOC) according to the Tyurin method [22],

- the content of total nitrogen (TN) by means of the Kjeldahl method [2],

- the content of total iron and aluminium $\left(\mathrm{Fe}_{t}, \mathrm{Al}_{\mathrm{t}}\right)$ by means of the microwave plasma atomic emission spectrometry (Agilent 4100 MP-AES) after samples digestion in a mixture of $60 \% \mathrm{HClO}_{4}$ and $40 \% \mathrm{HF}$,

- the content of "free" iron oxides $\left(\mathrm{Fe}_{\mathrm{d}}\right)$ by means of the microwave plasma atomic emission spectrometry (Agilent 4100 MP-AES) after samples extraction by means of the Jackson's method [20],

- the content of amorphous iron and aluminium oxides $\left(\mathrm{Fe}_{\mathrm{o}}, \mathrm{Al}_{\mathrm{o}}\right)$ by means of the microwave plasma atomic emission spectrometry (Agilent 4100 MP-AES) after samples extraction by means of the Schwertmann method [26].

\section{Quantification of soil forming processes}

Quantification of soil forming processes was performed based on iron forms and proposed by Jonczak [16] profile development index (PDI), calculated according to the formula:

$$
\mathrm{PDI}=\left|\frac{\text { weighted mean } \mathrm{Fe}_{\mathrm{d}} / \mathrm{Fe}_{\mathrm{t}} \text { in solum }}{\mathrm{Fe}_{\mathrm{d}} / \mathrm{Fe}_{\mathrm{t}} \text { in parent material }}+\% \mathrm{TOC} \cdot 2\right| \cdot \text { solum thickness [m] }
$$




\section{RESULTS AND DISCUSSION}

\section{Soil morphology and basic properties}

The solum of Haplic Chernozems was $90 \mathrm{~cm}$ in thickness in the profile Krakovany 1 and $80 \mathrm{~cm}$ in thickness in profile Krakovany 2. Bulk density of these soils ranged from 1.24 to $1.61 \mathrm{Mg} \mathrm{m}^{-3}$, total porosity - from 35,4 to $52,6 \%$ and soil moisture - from 25.7 to $33.0 \%$ (Table 1). Their $\mathrm{pH}$ was $6.6-8.2$, showing increasing trends with depth (Table 2). Parent materials contained up to $21.8 \%$ of carbonates, the trace quantities of which were also observed in A-horizons. The soils were relatively poor in TOC (4.0-13.0 $\mathrm{g} \mathrm{kg}^{-1}$ in A-horizons) and TN (0.48-1.42 $\left.\mathrm{g} \mathrm{kg}^{-1}\right)$. The thickness of solum in Cambic Chernozems was $40 \mathrm{~cm}$ in the profile of arable soil Báb 1 and $70 \mathrm{~cm}$ in forest soil Báb 2. Lower thickness of arable soil as compared to forest one reflected the impact of accelerated by tillage water erosion. Arable soil was characterised by lower porosity, particularly in A-horizon where it ranged from 39.7 to $45.2 \%$ against $55.8-69.4 \%$ in forest soil. Reaction of arable soil was within slightly acid in Ap and ABw horizons and alkaline in calcareous parent material (Table 2). In A-horizon of forest soil it was strongly acid and increased with depth until alkaline in Ck-horizon. The content of TOC gradually decreased with depth in solum of both soils and was $5.79-14.47 \mathrm{~g} \mathrm{~kg}^{-1}$ in the profile of arable soil and 7.01-50.72 $\mathrm{g} \mathrm{kg}^{-1}$ in forest soil. Related regularities in vertical distribution showed the content of TN, which was $0.39-1.42 \mathrm{~g} \mathrm{~kg}^{-1}$ and $0.51-3.71 \mathrm{~g} \mathrm{~kg}^{-1}$, respectively. Each of the studied soils was characterised by the presence of well-developed granular structure in A-horizons. Narrow TOC:TN ratios indicate high biological activity of the soils, regardless of their use type.

\section{The content and profile distribution patterns of iron and aluminium forms}

The content of total iron $\left(\mathrm{Fe}_{\mathrm{t}}\right)$ in the studied soils ranged from 21.78 to $32.48 \mathrm{~g} \mathrm{~kg}^{-1}$, showing relatively low variability between the individual profiles and vertical variability within each of them (Table 3). In Haplic Chernozems the highest contents of $\mathrm{Fe}_{\mathrm{t}}$ were noticed in bottom parts of A-horizon and in Cambic Chernozems in enriched horizons.

Larger variability showed the content of $\mathrm{Fe}_{\mathrm{d}}$, which ranged from 5.74 to $11.53 \mathrm{~g} \mathrm{~kg}^{-1} . \mathrm{Fe}_{\mathrm{d}} / \mathrm{Fe}_{\mathrm{t}}$ ratios, ranging from 0.26 to 0.39 , suggesting relatively low degree of weathering of mineral substrates. Profile distribution patterns in the content of free iron oxides and $\mathrm{Fe}_{\mathrm{d}} / \mathrm{Fe}_{\mathrm{t}}$ ratios reflect slight displacement of iron within the soils or/and variable intensity of weathering at different depths. The highest content of $\mathrm{Fe}_{\mathrm{d}}$ as well as the highest values of $\mathrm{Fe}_{\mathrm{d}} / \mathrm{Fe}_{\mathrm{t}}$ ratios in Haplic Chernozems were noticed in the bottom of A-horizons whereas in forest Cam- 
TABLE 1. PHYSICAL PROPERTIES OF THE SOILS

\begin{tabular}{|c|c|c|c|c|c|}
\hline Horizon & $\begin{array}{l}\text { Depth } \\
{[\mathrm{cm}]}\end{array}$ & Soil color & $\begin{array}{c}\text { Bulk density } \\
{\left[\mathrm{Mg} \mathrm{m}^{-3}\right]}\end{array}$ & $\begin{array}{c}\text { Total porosity } \\
{[\%]}\end{array}$ & $\begin{array}{c}\text { Water content } \\
{[\% \text { vol. }]}\end{array}$ \\
\hline \multicolumn{6}{|c|}{ Krakovany 1 - Haplic Chernozem } \\
\hline Ap & $0-10$ & $10 Y R 4 / 4$ & 1.38 & 43.7 & 33.0 \\
\hline \multirow[t]{2}{*}{ A2 } & $10-20$ & 10YR 3/4 & 1.61 & 35.4 & 32.7 \\
\hline & $20-30$ & 10YR 3/4 & 1.54 & 40.5 & 32.0 \\
\hline \multirow[t]{2}{*}{ A3 } & $30-40$ & 10YR 3/4 & 1.58 & 38.9 & 32.0 \\
\hline & $40-50$ & 10YR 3/4 & 1.44 & 44.8 & 29.7 \\
\hline \multirow[t]{3}{*}{ A4 } & $50-60$ & 10YR 3/4 & 1.40 & 46.3 & 30.3 \\
\hline & $60-70$ & 10YR 3/4 & 1.39 & 47.3 & 29.8 \\
\hline & $70-80$ & 10YR $3 / 4$ & 1.37 & 47.1 & 29.3 \\
\hline ACk & $80-90$ & 10YR 5/4 & - & - & - \\
\hline \multirow[t]{2}{*}{$\mathrm{Ck}$} & $90-100$ & 10YR 5/6 & - & - & - \\
\hline & $100-110$ & 10YR 4/4 & - & - & - \\
\hline \multicolumn{6}{|c|}{ Krakovany 2 - Haplic Chernozem } \\
\hline \multirow[t]{2}{*}{ Ap } & $0-10$ & $10 Y R 3 / 4$ & 1.24 & 52.6 & 25.7 \\
\hline & $10-20$ & 10YR 3/4 & 1.35 & 47.9 & 30.6 \\
\hline $\mathrm{A} 2$ & $20-30$ & 10YR 3/4 & 1.27 & 51.0 & 27.8 \\
\hline \multirow[t]{4}{*}{ A3 } & $30-40$ & 10YR 3/4 & 1.48 & 42.9 & 31.5 \\
\hline & $40-50$ & 10YR 3/4 & 1.40 & 46.2 & 30.9 \\
\hline & $50-60$ & 10YR 3/4 & 1.34 & 48.7 & 27.3 \\
\hline & $60-70$ & 10YR 3/4 & 1.35 & 48.7 & 28.8 \\
\hline ACk & $70-80$ & $10 Y R 4 / 4$ & 1.30 & 50.6 & 27.5 \\
\hline \multirow[t]{3}{*}{$\mathrm{Ck}$} & $80-90$ & 10YR 6/4 & - & - & - \\
\hline & $90-100$ & $10 Y R 6 / 4$ & - & - & - \\
\hline & $100-110$ & 10YR 3/4 & - & - & - \\
\hline \multicolumn{6}{|c|}{ Báb 1-Cambic Chernozems } \\
\hline \multirow[t]{2}{*}{$\mathrm{Ap}$} & $0-10$ & $10 \mathrm{YR} 2 / 3$ & 1.42 & 45.2 & 27.3 \\
\hline & $10-20$ & $10 Y R 2 / 3$ & 1.56 & 39.7 & 31.1 \\
\hline $\mathrm{ApBw}$ & $20-30$ & 10YR 3/4 & 1.42 & 44.6 & 28.6 \\
\hline $\mathrm{Bw}$ & $30-40$ & 10YR 5/6 & 1.35 & 48.1 & 18.9 \\
\hline \multirow[t]{3}{*}{$\mathrm{Ck}$} & $40-50$ & 10YR 7/3 & 1.40 & 46.9 & 5.4 \\
\hline & $50-60$ & $10 Y R 7 / 3$ & 1.32 & 50.2 & 12.9 \\
\hline & $60-70$ & 10YR 7/3 & 1.38 & 48.5 & 13.2 \\
\hline \multicolumn{6}{|c|}{ Báb 2 - Cambic Chernozems } \\
\hline A & $0-10$ & $10 Y R 2 / 3$ & 0.74 & 69.4 & 28.9 \\
\hline \multirow[t]{3}{*}{$\mathrm{A} 2$} & $10-20$ & 10YR 3/4 & 0.89 & 65.0 & 24.2 \\
\hline & $20-30$ & 10 YR $3 / 4$ & 1.13 & 55.8 & 24.6 \\
\hline & $30-40$ & 10YR 3/4 & 1.11 & 56.8 & 23.1 \\
\hline \multirow[t]{3}{*}{$\mathrm{ABw}$} & $40-50$ & $10 Y R 4 / 5$ & 1.31 & 49.8 & 26.1 \\
\hline & $50-60$ & $10 Y R 4 / 5$ & 1.29 & 50.6 & 24.3 \\
\hline & $60-70$ & 10YR 4/5 & 1.20 & 54.7 & 13.5 \\
\hline $\mathrm{Ck}$ & $70-80$ & 10YR 7/4 & 1.26 & 52.7 & 9.7 \\
\hline
\end{tabular}


TABLE 2. CHEMICAL PROPERTIES OF THE SOILS

\begin{tabular}{|c|c|c|c|c|c|c|}
\hline Horizon & $\begin{array}{l}\text { Depth } \\
{[\mathrm{cm}]}\end{array}$ & $\mathrm{pH}_{\mathrm{H} 2 \mathrm{O}}$ & $\begin{array}{c}\mathrm{CaCO}_{3} \\
{[\%]} \\
\end{array}$ & $\begin{array}{c}\text { TOC } \\
{\left[\mathrm{g} \mathrm{kg}^{-1}\right]}\end{array}$ & $\begin{array}{c}\mathrm{TN} \\
{\left[\mathrm{g} \mathrm{kg}^{-1}\right]}\end{array}$ & TOC:TN \\
\hline \multicolumn{7}{|c|}{ Krakovany 1 - Haplic Chernozem } \\
\hline Ap & $0-10$ & 7.5 & 0.3 & 13.7 & 1.42 & 9.6 \\
\hline \multirow[t]{2}{*}{ A2 } & $10-20$ & 7.5 & 0.2 & 9.8 & 1.21 & 8.1 \\
\hline & $20-30$ & 7.6 & 0.1 & 10.3 & 1.10 & 9.3 \\
\hline \multirow[t]{2}{*}{ A3 } & $30-40$ & 7.7 & 0.1 & 8.6 & 0.94 & 9.2 \\
\hline & $40-50$ & 7.8 & 0.4 & 7.4 & 0.96 & 7.7 \\
\hline \multirow[t]{3}{*}{ A4 } & $50-60$ & 7.9 & 0.2 & 5.7 & 0.94 & 6.1 \\
\hline & $60-70$ & 7.9 & 0.4 & 5.3 & 0.85 & 6.3 \\
\hline & $70-80$ & 7.9 & 0.7 & 4.2 & 0.51 & 8.2 \\
\hline $\mathrm{ACk}$ & $80-90$ & 8.0 & 7.1 & 4.8 & 0.48 & 10.0 \\
\hline \multirow[t]{2}{*}{$\mathrm{Ck}$} & $90-100$ & 8.2 & 17.2 & - & - & - \\
\hline & $100-110$ & 7.8 & 21.8 & - & - & - \\
\hline \multicolumn{7}{|c|}{ Krakovany 2 - Haplic Chernozem } \\
\hline \multirow[t]{2}{*}{ Ap } & $0-10$ & 6.7 & 0.0 & 12.9 & 1.14 & 11.4 \\
\hline & $10-20$ & 6.6 & 0.0 & 13.7 & 1.14 & 12.1 \\
\hline $\mathrm{A} 2$ & $20-30$ & 6.7 & 0.2 & 12.6 & 1.14 & 11.1 \\
\hline \multirow[t]{4}{*}{ A3 } & $30-40$ & 7.4 & 0.0 & 10.0 & 0.80 & 12.6 \\
\hline & $40-50$ & 7.8 & 0.3 & 8.2 & 0.60 & 13.6 \\
\hline & $50-60$ & 7.8 & 0.3 & 6.8 & 0.68 & 10.0 \\
\hline & $60-70$ & 7.9 & 0.9 & 5.0 & 0.48 & 10.5 \\
\hline $\mathrm{ACk}$ & $70-80$ & 8.0 & 7.5 & 6.4 & 0.50 & 12.9 \\
\hline \multirow[t]{3}{*}{$\mathrm{Ck}$} & $80-90$ & 8.1 & 16.5 & - & - & - \\
\hline & $90-100$ & 8.1 & 21.2 & - & - & - \\
\hline & $100-110$ & 8.1 & 20.4 & - & - & - \\
\hline \multicolumn{7}{|c|}{ Báb 1-Cambic Chernozems } \\
\hline \multirow[t]{2}{*}{ Ap } & $0-10$ & 6.5 & 0.0 & 14.2 & 1.42 & 10.0 \\
\hline & $10-20$ & 6.0 & 0.0 & 14.5 & 1.31 & 11.0 \\
\hline $\mathrm{ApBw}$ & $20-30$ & 6.5 & 0.0 & 8.7 & 0.60 & 14.6 \\
\hline $\mathrm{Bw}$ & $30-40$ & 6.9 & 0.0 & 5.8 & 0.39 & 14.8 \\
\hline \multirow[t]{3}{*}{$\mathrm{Ck}$} & $40-50$ & 7.9 & 15.2 & - & - & - \\
\hline & $50-60$ & 8.0 & 25.6 & - & - & - \\
\hline & $60-70$ & 8.1 & 24.4 & - & - & - \\
\hline \multicolumn{7}{|c|}{ Báb 2 - Cambic Chernozems } \\
\hline A & $0-10$ & 4.3 & 0.0 & 50.7 & 3.71 & 13.7 \\
\hline \multirow[t]{3}{*}{$\mathrm{A} 2$} & $10-20$ & 4.3 & 0.0 & 30.0 & 2.15 & 14.0 \\
\hline & $20-30$ & 4.9 & 0.0 & 15.0 & 1.74 & 8.6 \\
\hline & $30-40$ & 6.5 & 0.0 & 12.9 & 1.35 & 9.6 \\
\hline \multirow[t]{3}{*}{$\mathrm{ABw}$} & $40-50$ & 5.9 & 0.0 & 10.5 & 0.78 & 13.5 \\
\hline & $50-60$ & 5.9 & 0.0 & 7.0 & 0.56 & 12.5 \\
\hline & $60-70$ & 7.4 & 3.8 & 7.0 & 0.51 & 13.8 \\
\hline $\mathrm{Ck}$ & $70-80$ & 7.9 & 19.1 & - & - & - \\
\hline
\end{tabular}


bic Chernozems - in enriched horizons. In eroded arable Cambic Chernozems (profile Báb 1) the highest content of $\mathrm{Fe}_{\mathrm{d}}$ occurred in topsoil. Conditioned by the presence of carbonates is high $\mathrm{pH}$ the factor significantly limiting movement of free iron oxides in the investigated soils. Noteworthy are high contents of free iron oxides in parent materials of the investigated soils, as compared to their contents in solum.

Amorphous iron oxides, which occurred in amounts 0.77-2.94 $\mathrm{g} \mathrm{kg}^{-1}$ (Table 3), constituted 3-11\% of $\mathrm{Fe}_{\mathrm{t}}$. $\mathrm{Fe}_{\mathrm{o}} / \mathrm{Fe}_{\mathrm{d}}$ ratios at the level 0.09-0.33, indicating high degree of free iron oxides crystallisation. The highest $\mathrm{Fe}_{\mathrm{o}} / \mathrm{Fe}_{\mathrm{d}}$ ratios were in general noted in humus-rich and slightly acidified topsoil layers. Both low $\mathrm{pH}$ and the presence of humic substances are factors which do not favour crystallisation of free iron oxides [4].

The content of total aluminium was about twice higher as compared to the content of total iron, ranging from 47.06 to $61.74 \mathrm{~g} \mathrm{~kg}^{-1}$ and showing similar profile distribution patterns (Table 3). $\mathrm{Al}_{\mathrm{o}}$ content was $0.86-3.24 \mathrm{~g} \mathrm{~kg}^{-1}$, which constituted $2-6 \%$ of $\mathrm{Al}_{\mathrm{t}}$.

\section{Quantification of soil forming processes}

Transformation of mineral substrates in a result of weathering influenced by abiotic and biotic factors, accumulation and qualitative transformation of organic matter and movement of mineral and organic components, leading to the development of soil profiles with characteristic for specific layouts of soil-forming factors vertical sequences of genetic and diagnostic horizons are crucial symptoms of pedogenesis. An assessment of the degree of soil mineral substrates transformation during pedogenesis is usually based on the content of free iron oxides in total content of this element. However, the value of $\mathrm{Fe}_{\mathrm{d}} / \mathrm{Fe}_{\mathrm{t}}$ ratio in individual soil horizons resulting from the degree of mineral substrates weathering may be modified by leaching of free oxides by percolating waters or enriching in iron as a result of illuviation or crystallisation from groundwater. Therefore, to compare the degree of pedogenic transformation of soil mineral substrates in different soil types, the average $\mathrm{Fe}_{\mathrm{d}} / \mathrm{Fe}_{\mathrm{t}}$ ratio for solum should be applied. In the studied Chernozems, the average $\mathrm{Fe}_{\mathrm{d}} / \mathrm{Fe}_{\mathrm{t}}$ ratios were comparable among the profiles and ranged from 0.33 to 0.35 (Table 4), indicating moderate degree of weathering. A comprehensive assessment of the degree of mineral substrates pedogenic transformation and advancement of soil-forming processes requires consideration of not only the degree of weathering but also a number of other aspects of pedogenesis, such as solum thickness, accumulation of organic matter, pedogenic transformation of texture, colour and chemical features. Those factors are taken into account in calculation of quantitative indices of soil profiles development (PDI) [11, 21, 25]. However, complicated PDI indices are usually useful only for the soils of the same origin. It also should be referred to the fact that vertical variability of some 
TABLE 3. THE CONTENT OF IRON AND ALUMINIUM FORMS IN THE SOILS

\begin{tabular}{|c|c|c|c|c|c|c|c|c|c|}
\hline \multirow{2}{*}{ Horizon } & \multirow{2}{*}{$\begin{array}{c}\text { Depth } \\
{[\mathrm{cm}]}\end{array}$} & $\mathrm{Fe}_{\mathrm{t}}$ & $\mathrm{Fe}_{\mathrm{d}}$ & $\mathrm{Fe}_{0}$ & \multirow{2}{*}{$\mathrm{Fe}_{\mathrm{d}} / \mathrm{Fe}_{\mathrm{t}}$} & \multirow{2}{*}{$\mathrm{Fe}_{\mathrm{o}} / \mathrm{Fe}_{\mathrm{d}}$} & $\mathrm{Al}_{\mathrm{t}}$ & $\mathrm{Al}_{0}$ & \multirow{2}{*}{$\mathrm{Al}_{\mathrm{o}} / \mathrm{Al}_{\mathrm{t}}$} \\
\hline & & \multicolumn{3}{|c|}{$\left[\mathrm{g} \mathrm{kg}^{-1}\right]$} & & & \multicolumn{2}{|c|}{$\left[\mathrm{g} \mathrm{kg}^{-1}\right]$} & \\
\hline \multicolumn{10}{|c|}{ Krakovany 1 - Haplic Chernozem } \\
\hline Ap & $0-10$ & 25.44 & 8.20 & 2.36 & 0.32 & 0.29 & 50.29 & 1.38 & 0.03 \\
\hline \multirow[t]{2}{*}{ A2 } & $10-20$ & 26.25 & 8.49 & 2.39 & 0.32 & 0.28 & 51.90 & 1.48 & 0.03 \\
\hline & $20-30$ & 26.76 & 8.60 & 2.40 & 0.32 & 0.28 & 52.21 & 1.52 & 0.03 \\
\hline \multirow[t]{2}{*}{ A3 } & $30-40$ & 27.00 & 8.59 & 2.42 & 0.32 & 0.28 & 52.47 & 1.62 & 0.03 \\
\hline & $40-50$ & 28.53 & 9.97 & 1.83 & 0.35 & 0.18 & 57.25 & 1.66 & 0.03 \\
\hline \multirow[t]{3}{*}{ A4 } & $50-60$ & 30.13 & 11.10 & 1.88 & 0.37 & 0.17 & 58.60 & 1.79 & 0.03 \\
\hline & $60-70$ & 30.90 & 10.92 & 1.77 & 0.35 & 0.16 & 58.97 & 1.72 & 0.03 \\
\hline & $70-80$ & 30.90 & 10.69 & 2.06 & 0.35 & 0.19 & 59.20 & 1.79 & 0.03 \\
\hline $\mathrm{ACk}$ & $80-90$ & 27.78 & 9.46 & 2.00 & 0.34 & 0.21 & 55.79 & 1.69 & 0.03 \\
\hline \multirow[t]{2}{*}{$\mathrm{Ck}$} & $90-100$ & 24.08 & 8.01 & 1.67 & 0.33 & 0.21 & 50.73 & 1.39 & 0.03 \\
\hline & $100-110$ & 22.45 & 7.10 & 1.73 & 0.32 & 0.24 & 48.76 & 1.20 & 0.02 \\
\hline \multicolumn{10}{|c|}{ Krakovany 2 - Haplic Chernozem } \\
\hline \multirow[t]{2}{*}{ Ap } & $0-10$ & 28.30 & 9.50 & 2.34 & 0.34 & 0.25 & 55.42 & 1.62 & 0.03 \\
\hline & $10-20$ & 28.41 & 9.63 & 2.36 & 0.34 & 0.25 & 55.28 & 1.73 & 0.03 \\
\hline A2 & $20-30$ & 28.31 & 9.34 & 2.39 & 0.33 & 0.26 & 55.72 & 1.64 & 0.03 \\
\hline \multirow[t]{4}{*}{$\mathrm{A} 3$} & $30-40$ & 29.65 & 10.33 & 2.20 & 0.35 & 0.21 & 57.88 & 1.90 & 0.03 \\
\hline & $40-50$ & 30.01 & 10.32 & 2.24 & 0.34 & 0.22 & 58.87 & 2.11 & 0.04 \\
\hline & $50-60$ & 30.36 & 10.70 & 2.38 & 0.35 & 0.22 & 58.48 & 2.12 & 0.04 \\
\hline & $60-70$ & 30.08 & 10.18 & 2.67 & 0.34 & 0.26 & 58.88 & 2.16 & 0.04 \\
\hline $\mathrm{ACk}$ & $70-80$ & 28.28 & 8.81 & 2.53 & 0.31 & 0.29 & 57.66 & 2.03 & 0.04 \\
\hline \multirow[t]{3}{*}{$\mathrm{Ck}$} & $80-90$ & 24.05 & 7.18 & 1.98 & 0.30 & 0.28 & 51.24 & 1.40 & 0.03 \\
\hline & $90-100$ & 22.52 & 6.49 & 1.79 & 0.29 & 0.27 & 48.76 & 1.14 & 0.02 \\
\hline & $100-110$ & 22.50 & 6.50 & 1.83 & 0.29 & 0.28 & 49.85 & 1.06 & 0.02 \\
\hline \multicolumn{10}{|c|}{ Báb 1 - Cambic Chernozems } \\
\hline \multirow[t]{2}{*}{ Ap } & $0-10$ & 28.98 & 10.66 & 2.88 & 0.37 & 0.27 & 57.36 & 2.32 & 0.04 \\
\hline & $10-20$ & 29.36 & 10.21 & 2.90 & 0.35 & 0.28 & 58.29 & 2.30 & 0.04 \\
\hline $\mathrm{ApBw}$ & $20-30$ & 32.48 & 10.89 & 2.45 & 0.34 & 0.23 & 61.71 & 2.20 & 0.04 \\
\hline $\mathrm{Bw}$ & $30-40$ & 32.15 & 10.72 & 2.08 & 0.33 & 0.19 & 61.74 & 2.03 & 0.03 \\
\hline \multirow[t]{3}{*}{$\mathrm{Ck}$} & $40-50$ & 26.09 & 7.23 & 1.37 & 0.28 & 0.19 & 54.22 & 1.45 & 0.03 \\
\hline & $50-60$ & 21.98 & 5.79 & 1.09 & 0.26 & 0.19 & 47.87 & 1.08 & 0.02 \\
\hline & $60-70$ & 21.78 & 5.74 & 1.02 & 0.26 & 0.18 & 47.06 & 0.86 & 0.02 \\
\hline \multicolumn{10}{|c|}{ Báb 2 - Cambic Chernozems } \\
\hline $\mathrm{A}$ & $0-10$ & 27.39 & 8.98 & 2.94 & 0.33 & 0.33 & 52.31 & 3.24 & 0.06 \\
\hline \multirow[t]{3}{*}{ A2 } & $10-20$ & 28.62 & 9.20 & 2.73 & 0.32 & 0.30 & 53.50 & 3.14 & 0.06 \\
\hline & $20-30$ & 28.63 & 8.38 & 2.43 & 0.29 & 0.29 & 54.17 & 2.65 & 0.05 \\
\hline & $30-40$ & 29.07 & 8.55 & 2.35 & 0.29 & 0.27 & 55.13 & 2.42 & 0.04 \\
\hline \multirow[t]{3}{*}{$\mathrm{ABw}$} & $40-50$ & 32.09 & 10.24 & 2.23 & 0.32 & 0.22 & 58.99 & 2.24 & 0.04 \\
\hline & $50-60$ & 32.02 & 10.94 & 1.65 & 0.34 & 0.15 & 58.35 & 2.01 & 0.03 \\
\hline & $60-70$ & 29.65 & 11.53 & 1.26 & 0.39 & 0.11 & 55.89 & 1.64 & 0.03 \\
\hline $\mathrm{Ck}$ & $70-80$ & 24.14 & 8.63 & 0.77 & 0.36 & 0.09 & 49.67 & 1.09 & 0.02 \\
\hline
\end{tabular}


TABLE 4. QUANTITATIVE INDICES OF SOILS DEVELOPMENT

\begin{tabular}{|c|c|c|c|c|}
\hline & Krakovany 1 & Krakovany 2 & Báb 1 & Báb 2 \\
\cline { 2 - 5 } & \multicolumn{2}{|c|}{ Haplic Chernozems } & \multicolumn{2}{c|}{ Cambic Chernozems } \\
\hline Average $\mathrm{Fe}_{\mathrm{d}} / \mathrm{Fe}_{\mathrm{t}}$ in solum & 0.34 & 0.34 & 0.35 & 0.33 \\
PDI & 1.50 & 1.76 & 1.15 & 2.12 \\
\hline
\end{tabular}

soil properties, such as colour and $\mathrm{pH}$, may result not only from pedogenic transformations. Furthermore, the presence of lithological discontinuities is still another factor complicating the assessment. Bearing in mind those limitations, Jonczak [16] has developed a simple PDI based on the most important signs of pedogenesis, which allows to compare soils developed from different parent materials and in a result of various soil-forming processes. The proposed PDI index includes the degree of weathering of mineral substrates in solum, accumulation of organic matter, and thickness of solum. The applied PDI index clearly differentiates the studied Chernozems, ranging from 1.15 to 2.12 , representing the lowest value in eroded arable soil in the stand Báb 1 and the highest one in humus-rich forest soil in the stand Báb 2 (Table 4). In general, PDI values for the investigated soils are relatively low, comparable to those observed by Jonczak [16] in different soil types of young-glacial high plain areas of Leśna Creek catchment in Northern Poland. Low values of PDI in the investigated soils resulted from small differences between solum and parent materials in $\mathrm{Fe}_{\mathrm{d}} / \mathrm{Fe}_{\mathrm{t}}$ ratios.

\section{CONCLUSIONS}

The studied Chernozems were moderately abundant in total iron, the content of which showed relatively low variability between the individual profiles and vertical variability in each of them. Free iron oxides constituted 26-39\% of $\mathrm{Fe}_{\mathrm{t}}$, which indicated low and medium degree of weathering of mineral substrates. Vertical variability in $\mathrm{Fe}_{\mathrm{d}} / \mathrm{Fe}_{\mathrm{t}}$ ratios suggested slight displacement of iron or/and variable intensity of weathering at different depths. The high content of free iron oxides in parent materials was the characteristic feature of the studied soils as compared to solum. Crystalline forms of iron predominated over amorphous. The content of total aluminium was about twice higher than iron, however profile distribution patterns of this element were comparable to iron. Amorphous oxides of aluminium occurred in small quantities and their contribution in $\mathrm{Al}_{\mathrm{t}}$ did not exceed 6\%. Degree of mineral substrates weathering, abundance in organic matter, and thickness of solum in individual soil profiles were reflected in the varied PDI, which ranged from 1.15 to 2.12 . The values of that index also clearly reflected the influence of soil erosion and use type. The relatively low PDI values observed in the investigated Chernozems as compared to the literature-related data resulted mainly from only small differences in $\mathrm{Fe}_{\mathrm{d}} / \mathrm{Fe}_{\mathrm{t}}$ ratios between solum and parent materials. 


\section{REFERENCES}

[1] B e d n a r e k R.: Wiek, geneza i stanowisko systematyczne gleb rdzawych w świetle badań paleopedologicznych w okolicy Osia (Bory Tucholskie). Rozprawy UMK, Torun, 102, 1991.

[2] B r a d stre e t, R.B.: The Kjeldahl Method for Organic Nitrogen. Academic Press Inc., New York, 1965.

[3] Contin M., Mondini C., Le ital L., De Nobili M.: Geoderma, 140, 164, 2007.

[4] C o r n e 11 R.M., Schwertmann U.: Clays Clay Minerals, 27, 402, 1979.

[5] D ą b k o w s k a - N a s k rę t H.: Roczn. Glebozn., 47(3/4), 23, 1996.

[6] D ą b k o w s k a - N a s kr ę t H.: J. Plant Nutrition, 23, 1549, 2000.

[7] D e górski M., Kowalkowski A., Kozłowska A.: Gleby bielicoziemne - geograficzne trendy oraz dyskontynuacje procesów rozwoju, SEDNO Wyd. Akademickie, Warszawa, $381,2013$.

[8] D ziadow i e c H.: Rozkład ściółek w wybranych ekosystemach leśnych, Wydawnictwo UMK, Toruń, 137, 1990.

[9] Eusterhues K., N eidhardt J., Hädrich A., Küsel K., Totsche K.U.: Biogeochemistry, 119, 45, 2014.

[10] E v a n s L.J., W i 1 s o n W.G.: Canadian J. Soil Sci., 65, 489, 1985.

[11] Hard e n J.W.: Geoderma, 28, 1, 1982.

[12] IUSS Working Group WRB: World Reference Base for Soil Resources 2014, World Soil Resources Reports, 106, 2015.

[13] J o n c z a k J.: Sylwan,155(11), 760, 2011.

[14] J o n c z a k J: Soil Sci. Annual, 64(1), 9, 2013.

[15] J o n c z a k J.: Sylwan, 158, 621, 2014.

[16] J o n c zak J.: Geneza, ewolucja i właściwości gleb dolin rzek źródłowych w młodoglacjalnych obszarach zastoiskowych na przykładzie Leśnej (Równina Sławieńska). Wyd. Nauk. Akademii Pomorskiej, Słupsk, 2015.

[17] Kögel-Knabner I, Guggenberger G, Kleber M, Kandeler E, Kalbitz K, Scheu S, Eusterhues K, Le inweber P.: J. Plant Nut.Soil Sci., 171, 61, 2008.

[18] K o n e c k a - B et l e y K.: Roczn. Glebozn., 19(1), 51, 1968.

[19] M c K e a g u e J.A., D a y J.H.: Canadian J. Soil Sci., 46, 13, 1966.

[20] M e hr a O., J a c k s o n J.: Clay Clay Minerals, 5, 317, 1960.

[21] M o n r o e J.S., B o c k h e i m J.G.: Arctic, Antarctic, and Alpine Research, 33(1), 78, 2001.

[22] Orlov, V., Grishina, I.: Guide of humus chemistry. Moscow University Publishing, Moscow, 1981.

[23] O y a m a M., Takeh ar a H.: Revised Standard Soil Color Charts, 2nd Edition, Research Council for Agriculture, Forestry and Fisheries, Ministry of Agriclutlure, Tokyo, 1967.

[24] Š pánik R., Re pa Š., Š išk a B.: Agroklimatické a fenologické pomery Nitry (19912000), SPU, Nitra, 2002.

[25] S w a n s on T.W., E 11 i o t t- F is k D.L., S o uthard R.J.: Quaternary Research, 39, 186, 1993.

[26] Van Reeuwijk L.: Procedures for Soil Analysis. Tech. Paper 9, ISRIC, 1995. 


\section{CHARAKTERYSTYKA FORM ŻELAZA I GLINU ORAZ KWANTYFIKACJA PROCESÓW GLEBOTWÓRCZYCH W CZARNOZIEMACH ZACHODNIEJ SŁOWACJI}

Artykuł prezentuje wyniki badań nad zawartością form żelaza i glinu oraz kwantyfikacją procesów glebotwórczych w czarnoziemach zachodniej Słowacji. Dwa profile uprawnych czarnoziemów typowych zlokalizowano w miejscowości Krakovany, a dwa kolejne, reprezentujące uprawne i leśne czarnoziemy z poziomem cambic w miejscowości Báb. W pobranych z warstw co $10 \mathrm{~cm}$ próbkach oznaczono właściwości fizyczne i chemiczne stosując standardowe metody analityczne. Na podstawie wyników analiz dla każdego z profili obliczono wskaźniki PDI. Czarnoziemy w Krakovanach, o miąższości solum $90 \mathrm{~cm}$ (Krakovany 1) i $80 \mathrm{~cm}$ (Krakovany 2), charakteryzowały się odczynem od obojętnego do zasadowego, wykazującym tendencję wzrostową $\mathrm{z}$ głębokością. Zawierały one do $13,70 \mathrm{~g} \mathrm{~kg}^{-1}$ węgla organicznego w obydwu profilach. Czarnoziemy z poziomem cambic w miejscowości Báb charakteryzowały się mniejszą miąższością solum, wynoszącą $40 \mathrm{~cm}$ w profilu gleby uprawnej (Báb 1) i $70 \mathrm{~cm}$ w profilu gleby leśnej (Báb 2). Odczyn gleb uprawnych mieścił się w przedziale od słabo kwaśnego do zasadowego, a leśnych od silnie kwaśnego do zasadowego, wykazując tendencję wzrostową wraz z głębokością. Gleby uprawne zawierały 14,2-14,5 $\mathrm{g} \mathrm{kg}^{-1}$, a gleby leśne 12,9-50,7 $\mathrm{g} \mathrm{kg}^{-1}$ węgla organicznego. Zawartość żelaza ogółem $\left(\mathrm{Fe}_{\mathrm{t}}\right)$ w badanych glebach wynosiła od 21,78 do $32,48 \mathrm{~g} \mathrm{~kg}^{-1}$, żalaza wolnego $\left(\mathrm{Fe}_{\mathrm{d}}\right)$ 5,74-11,53 $\mathrm{g} \mathrm{kg}^{-1}$, a jego amorficznych form $\left(\mathrm{Fe}_{\mathrm{o}}\right)$ 0,77-2,94 $\mathrm{g} \mathrm{kg}^{-1}$. Wartości stosunków $\mathrm{Fe}_{\mathrm{d}} / \mathrm{Fe}_{\mathrm{t}}$, wynosiły 0,26-0,39. W puli żelaza wolnego dominowały tlenki krystaliczne. Uzyskane wartości wskaźnika PDI były stosunkowo niskie, wynosząc 1,50 w profilu Krakovany 1, 1,76 w profilu Krakovany 2, 1,15 w profilu Báb 1 i 2,12 w profilu Báb 2. 